\title{
Environmental drivers of the bryophyte propagule bank and its comparison with forest-floor assemblage in Central European temperate mixed forests
}

\section{Anna Kövendi-Jakó, Sára Márialigeti, András Bidló \& Péter Ódor}

To cite this article: Anna Kövendi-Jakó, Sára Márialigeti, András Bidló \& Péter Ódor (2016) Environmental drivers of the bryophyte propagule bank and its comparison with forest-floor assemblage in Central European temperate mixed forests, Journal of Bryology, 38:2, 118-126, DOI: 10.1080/03736687.2015.1115804

To link to this article: http://dx.doi.org/10.1080/03736687.2015.1115804

曲 Published online: 10 Feb 2016.

Submit your article to this journal $₫$

ЦIl Article views: 64

View related articles $\longleftarrow$

View Crossmark data \lceil 


\title{
Environmental drivers of the bryophyte propagule bank and its comparison with forest-floor assemblage in Central European temperate mixed forests
}

\author{
Anna Kövendi-Jakón ${ }^{1}$, Sára Márialigeti ${ }^{1}$, András Bidló ${ }^{2}$, Péter Ódor 3 \\ ${ }^{1}$ Department of Plant Taxonomy, Ecology and Theoretical Biology, Loránd Eötvös University, Budapest, \\ Hungary, ${ }^{2}$ Institute of Environmental and Earth Sciences, University of West Hungary, Sopron, Hungary, ${ }^{3}$ MTA \\ Centre for Ecological Research, Institute of Ecology and Botany, Vácrátót, Hungary
}

\begin{abstract}
Species richness, composition and abundance of the bryophyte diaspore bank of Central European temperate mixed forests were compared with the forest-floor bryophyte assemblage. The impact of environmental variables and anthropogenic disturbances, including tree species composition, stand structure, microclimate, light conditions, soil and litter properties, management history, and landscape properties, potentially influencing bryophyte diaspore bank assemblages were explored. Thirty-four, 70-100 years old mixed stands with differing tree species composition were examined in the Örség National Park, Western Hungary. The diaspore bank was studied by soil collection and cultivation, and data were analysed by multivariate methods. Contrary to the forest-floor bryophyte assemblage, where substrate availability, tree species composition and stand structure were the most influential environmental variables, the composition and abundance of the diaspore bank was mainly affected by site conditions (microclimate, litter and soil properties). Species richness of the bryophyte diaspore bank was lower than that of the forest-floor bryophyte assemblage. Short-lived mosses (colonists, short-lived shuttles) were dominant in the diaspore bank, as opposed to the forest-floor bryophyte community, where perennial mosses dominated. In the studied forests, the importance of the bryophyte diaspore bank was relatively low in the regeneration and maintenance of the forest-floor bryophyte vegetation.
\end{abstract}

Keywords: Diaspore bank, Ordination, Species composition, Species richness

\section{Introduction}

Reservoirs of dormant reproductive propagules are known from several groups, such as phanerogams (seed bank), ferns, bryophytes (diaspore bank), dinoflagellates and copepods. Their role is increasingly appreciated in nature conservation, restoration, life history analysis and population genetics. The diaspore bank of bryophytes is less well known than the soil seed bank of phanerogams (During, 1997; Csontos, 2001). The soil contains a "bank" of bryophyte diaspores, including "a number of dormant, ungerminated but viable spores and/or asexual propagules: rhizoidal or protonemal gemmae, tubers, and resting buds on stem fragments" (During, 2001). The different types of propagules have been generally thought to have different functions: the spores are mainly important for long-distance dispersal while asexual reproduction maintains local populations.

Correspondence to: Anna Kövendi-Jakó, Department of Plant Taxonomy, Ecology and Theoretical Biology, Loránd Eötvös University, Pázmány P. stny. 1/C, 1117 Budapest, Hungary. Email: kjanna14@gmail.com.
The lifetime of spores is longer, their dispersal ability is better and their germination capability is worse than that of asexual diaspores (During, 1979). The production of spores is usually strongly seasonally determined (Hock et al., 2004), while the production of asexual diaspores is usually much less seasonal (During, 1997, 2001). In contrast to the seed bank of phanerogams, the bryophyte diaspore bank is dominated by asexual propagules (During, 1997, 2001; Longton, 1997; Söderström \& Herben, 1997; LaakaLindberg, 1999; Rydin, 2009). Bryophytes are classified into life strategy types, based on the life span, reproductive effort of the gametophyte, and size and abundance of spores (During, 1979, 1992). Usually bryophyte species are not all represented equally well in the diaspore bank. Pleurocarpous, perennial bryophytes that dominate the above-ground vegetation tend to be underrepresented in the diaspore bank, because they have low reproductive effort and long life span in the forest-floor assemblages. By contrast, 
acrocarpous colonists, and annual and short-lived shuttle species are dominant in the soil diaspore bank even in the vegetation types where the aboveground vegetation is dominated by perennial pleurocarpous bryophytes. These bryophyte species have persistent spores and high sexual and asexual reproductive effort, short life span in the forest-floor vegetation and they have an important role in the regeneration of forest-floor bryophyte vegetation after disturbance (During, 1979, 1992, 1997, 2001; Vanderpooren \& Goffinet, 2009). Many species of the propagule bank are not well represented in the vegetation; even scientifically new taxa have been described from diaspore bank, such as the species Neophoenix matoposensis and Ephemerum spp. (Zander \& During, 1999).

Most studies have demonstrated that the diaspore bank has similar or greater diversity than the aboveground vegetation (Jonsson, 1993; Rydgren \& Hestmark, 1997; Hock et al., 2008). In addition to the aforementioned importance in bryophyte diversity, the role of the bryophyte propagule bank is diverse: ensuring the survival of bryophytes under unfavourable conditions and after disturbance, facilitating regeneration and colonization, and regulating population size (Van Tooren et al., 1990; Jonsson, 1993; Lloret, 1994; During, 1995, 1997; Hock et al., 2008; Caners et al., 2009; Vanderpoorten \& Goffinet, 2009). While for phanerogams many types of dormancy and dormancy-breaking mechanisms have been described, in the case of bryophyte propagules, knowledge is sparse (Sundberg \& Rydin, 2000; During, 2001; Hock et al., 2004).

Most important drivers of species composition, structure and spatial pattern of bryophyte assemblages are different for the forest-floor vegetation and propagule bank, but forest-floor vegetation has been more intensively studied. In temperate and boreal forests, the most important drivers for forest-floor bryophytes are mainly microclimate (Mills \& Macdonald, 2005; Hylander \& Dynesius, 2006), soil conditions (Hylander \& Dynesius, 2006) and availability of appropriate substrates (Schofield, 1985; Ódor \& Standovár, 2002; Ódor \& van Hees, 2004; Wiklund \& Rydin, 2004). Márialigeti et al. (2009) demonstrated that the litter of deciduous trees has a negative effect on the occurrence of forest floor bryophytes, which are restricted to open mineral soil and logs. Stand structure heterogeneity, tree species richness and the presence of a regeneration (shrub) layer considerably increases bryophyte cover and diversity (Aude \& Lawesson, 1998; Márialigeti et al., 2009).

In contrast to forest-floor bryophytes, the relationship between forest site conditions and the bryophyte diaspore bank has hardly been studied (Caners $e t$ al., 2009). Comparative studies between forest-floor bryophytes and diaspore banks in forests are also sparse (During et al., 1987; Jonsson, 1993; Rydgren \& Hestmark, 1997; Hebrard, 2001; Rydgren et al., 2004; Szücs, 2013; Iglesias et al., 2015). Our investigation aimed to explore the environmental drivers of the diversity and composition of the bryophyte diaspore bank of temperate mixed forests, and to compare it with the forest-floor bryophyte assemblage. The study covered a wide range of potentially influential environmental variables (including tree species composition, stand structure, microclimate, light conditions, soil and litter properties, management history and landscape properties) in order to select the most important ones for diaspore bank composition and richness. In addition, the species richness and species composition of the diaspore bank and the forest-floor bryophyte vegetation were compared.

\section{Materials and Methods \\ Study area}

The study was located in the Örség National Park, Western Hungary $\left(46^{\circ} 51-55^{\prime} \mathrm{N}\right.$ and $\left.16^{\circ} 07-23^{\prime} \mathrm{W}\right)$. The landscape consists of hills and wide valleys, 250-350 $\mathrm{m}$ above sea level. The mean annual precipitation is $700-800 \mathrm{~mm}$ and mean yearly temperature is $9.0-9.5^{\circ} \mathrm{C}$ (Gyöngyössy, 2008). The superficial deposits are composed of Pleistocene sediments including loess and alluvial gravel. The soil is acidic ( $\mathrm{pH}$ 4.5-4.7) and nutrient poor; the most common soil type on hills is pseudogleyic and lessivaged brown forest soil (Luvisols), while in the valleys mire and meadow soils (Gleysols) can be found (Szodfridt, 1969).

Örség is a unique part of Hungary because different combinations of tree species appear under similar site conditions. Many tree species are found with relatively high abundance and various proportions in the stands, the dominant ones being beech (Fagus sylvatica), sessile and pedunculate oak (Quercus petraea and Quercus robur), hornbeam (Carpinus betulus), Scotch pine (Pinus sylvestris) and Norway spruce (Picea abies). The proportion of different associated species (such as Betula pendula, Populus tremula, Castanea sativa, Prunus avium) is also considerable. Most of the forest stands are mixed, with relatively high tree species diversity. Differences in species composition are the result of climate, and historical land use patterns.

This region of Hungary has been influenced by agriculture for centuries. Since the twelfth century extensive farming has decreased forest cover and resulted in a shifting mosaic of land use types. Litter collection in forests and a special form of tillage, ridging, changed the vegetation, and also resulted in the acidification of the soil and increased soil erosion. These processes are advantageous to Scotch pine 
regeneration, the establishment of a high terricolous bryophyte cover (Pleurozium schreberi, Scleropodium purum, Dicranum polysetum, Polytrichum formosum), and acidophytic shrub and herbaceous species (Ódor et al., 2002; Tímár et al., 2002). From the nineteenth century extensive farming decreased; the former arable lands reverted to forests, dominated by Scotch pine and other pioneer tree species. Two types of forest management are used nowadays: in private forests, a stem selection system is followed resulting in uneven aged stands; in state forests, a shelterwood management system is used, creating even aged stands with a rotation period of 70-100 years. After the stabilization of land use types, the species composition of the managed forests is changing, the dominance of deciduous tree species (beech, oaks, hornbeam) is increasing, while that of Scots pine and pioneer trees is decreasing (Tímár et al., 2002).

\section{Data collection}

Thirty-five forest stands ( $2-15$ ha each) were selected for this study by stratified random sampling from the stand structural database of the Hungarian National Forest Service. Criteria of site selection were as follows: all stands were 70-100 years old, located on level areas (slopes were less than $10^{\circ}$ ), and not directly influenced by water. The 293 stands meeting these criteria were grouped according to tree species composition representing different combinations of the main tree species (beech, sessile and pedunculate oak, Scots pine). The main groups were monodominant stands of one species (cover higher than 80\%) and mixed forests dominated by two or three of the aforementioned species. The 35 stands were randomly selected from these groups. The selected stands represent old growth forests, covering the different common tree species combinations in the area. The abundance of forest-floor bryophyte species (including species occurring on lying dead wood) was expressed in cover, which was estimated in $\mathrm{dm}^{2}$ within each $30 \mathrm{~m} \times 30 \mathrm{~m}$ plot. The total abundance of the terrestrial bryophyte layer per plot was expressed as the sum of the cover of the individual species.

Three bryophyte diaspore bank samples were collected in each $30 \mathrm{~m} \times 30 \mathrm{~m}$ plot in November 2009 . Soil cubes with $7 \mathrm{~cm}$ side length were taken out after the litter and other organic materials were removed from the surface. The soil cubes were put into paper bags and transported to the laboratory for cultivation. Altogether 105 sampling units were collected (35 plots, three subunits per plot).

During cultivation, a thin layer of the soil sampled (0.5-1.5 cm deep) was spread out in closed, transparent boxes (with $10 \mathrm{~cm}$ radius) on a layer of $c a 2-4 \mathrm{~cm}$ of autoclaved perlite, moistened with deionized water. Three control boxes containing autoclaved perlite layer with a thin autoclaved soil layer were also included for detecting air-borne propagule contamination. The samples were cultivated in greenhouse for 3 months as in Hock et al. (2004), finishing at the end of January 2010. Cultivation was at room temperature $\left(18-21^{\circ} \mathrm{C}\right.$ ), with natural (from 8 to 16 hours) and artificial (from 16 to 18 hours) light conditions (1200-2200 lx).

The abundance of the diaspore bank species within the sampling units was expressed by local frequency values. A frame $7 \mathrm{~cm} \times 7 \mathrm{~cm}$ divided into $1 \mathrm{~cm}^{2}$ sized squares by a grid was put into the cultivation box. Presence/absence of species was recorded within the squares. The maximum local frequency value of a species was $147(3 \times 49)$ within a plot. Abundance of the whole diaspore bank was expressed as the sum of the local frequencies of the individual species. Voucher specimens are deposited in the private herbarium of the last author. The identification of the young, atypical specimens was sometimes complicated (During, 1997). Sphagnum spp. and Ditrichum spp. (mainly D. pusillum, D. cylindricum and D. pallidum) were identified only at genus level. Nomenclature follows Erzberger and Papp (2004) for bryophytes and Tutin et al. (1964-1993) for vascular plants.

Fifty-two environmental variables were recorded for analysis (Table 1). Variables related to tree species composition and tree size (species identity, diameter, height) were based on measurements of tree individuals larger than $5 \mathrm{~cm}$ diameter at breast height (DBH) within the plots. Number of saplings (including trees and shrubs) thinner than $5 \mathrm{~cm}$ DBH but taller than $0.5 \mathrm{~m}$ were counted and their density (unit per hectare) was calculated. For dead wood volume calculation, only individuals thicker than $5 \mathrm{~cm}$ were included (snags and logs separately). Cover of understory vegetation (including herbs and seedlings shorter than $0.5 \mathrm{~m}$ ), bryophytes and different substrate types (mineral soil, deadwood and litter) were estimated (on plots of $30 \mathrm{~m} \times 30 \mathrm{~m}$ ). Canopy openness was measured with a spherical densitometer, and relative diffuse light with LAI-2000 Plant Canopy Analyser instruments; in both cases, the measurements were carried out at 36 points within the plots at $1.3 \mathrm{~m}$ height (Tinya et al., 2009).

Microclimate (air humidity and temperature) was measured in the middle of the plots at $1.3 \mathrm{~m}$ height using Voltcraft DL-120 TH data loggers in 24-hour measurement durations, eight times during two years. The microclimate of the forest stands in general, rather than that of the bryophyte communities (sensu Király et al., 2013) was recorded. Characteristics of litter and soil were surveyed in five sampling units per plot. Litter was collected from $30 \mathrm{~cm} \times 30 \mathrm{~cm}$ areas, but only the upper $10 \mathrm{~cm}$ layer was studied. The litter properties analysed were $\mathrm{pH}$, weight, composition of litter 
Table 1 Potential explanatory variables used to characterize the ecological conditions of the analysed forest stands

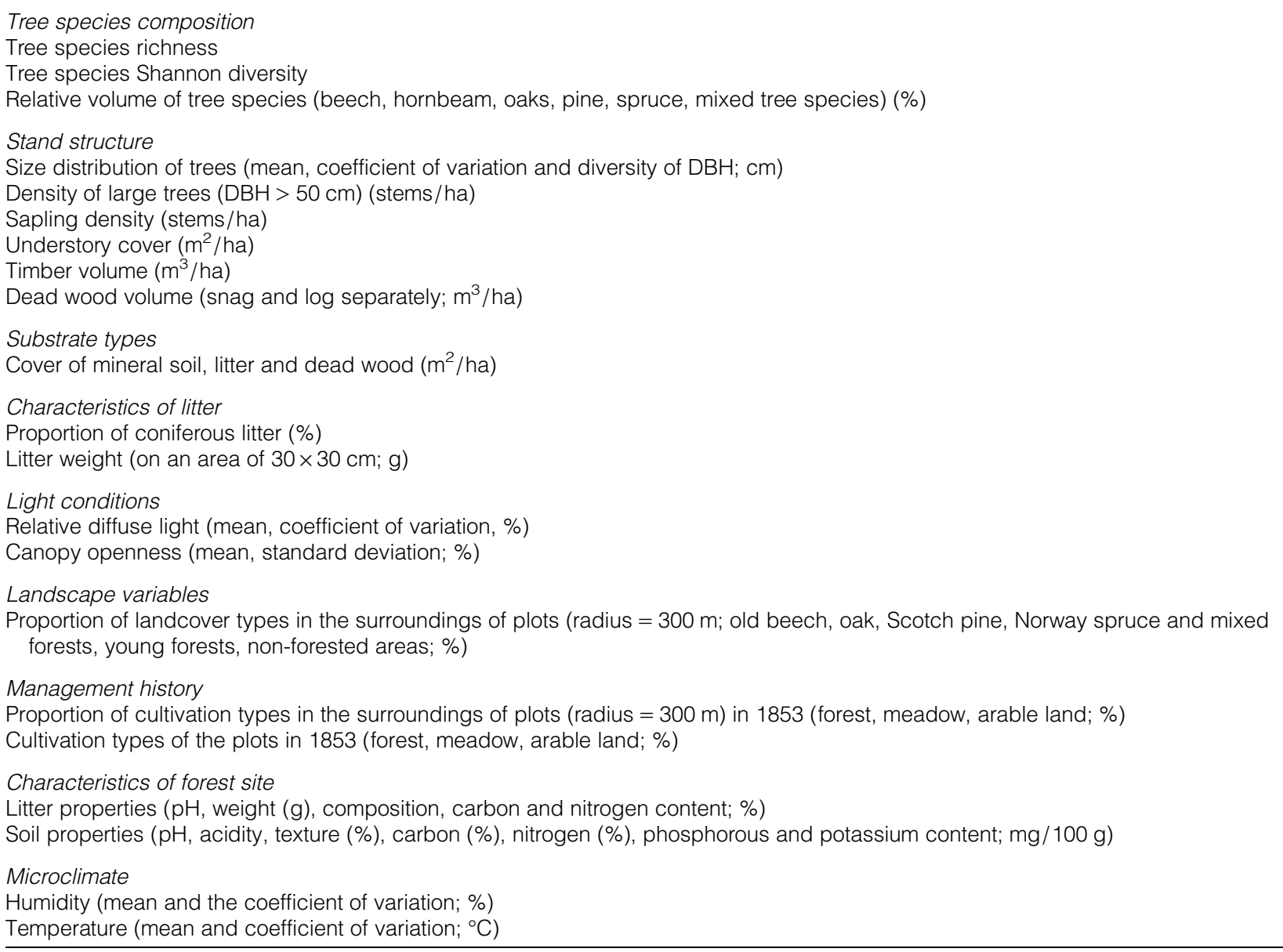

types (deciduous, coniferous, decayed), carbon and nitrogen content. We also considered the following mineral soil properties: $\mathrm{pH}$, acidity, texture, carbon, nitrogen, phosphorous and potassium content (Juhász et al., 2011). The proportion of land-cover types were estimated within circles of $300 \mathrm{~m}$ radius around the plots by remote sensing based on aerial photos, maps and data from the Hungarian Natural Forest Service (Márialigeti et al., 2009). Historical variables were generated based on the map of the Second Military Survey of the Habsburg Empire from 1853 (Arcanum, 2006). The management type of the plots and the proportion of these within a circle of $300 \mathrm{~m}$ radius were calculated (Table 1; Király \& Ódor, 2010).

\section{Data analysis}

The species richness, abundance and species composition of the diaspore bank and the forest-floor bryophyte assemblages were compared both at plot level (alpha diversity) and whole sample species richness (gamma diversity). Because of non-normal distribution and non-equal variances, plot level species richness was compared by Mood median test (Zar, 1999). Correlation of plot level species richness and plot level abundance was calculated between the two assemblages. The species composition was compared based on frequency data (based on occurrences in 35 plots) and the abundance data of the species. The relationship between the composition of the two assemblages was expressed as the matrix correlation of their distance matrices (Mantel-test, Legendre \& Legendre, 1998). Euclidean distance matrices between the plots were calculated for the two assemblages, based on the abundance values of the species (for diaspore bank: local frequency data; for forest-floor vegetation cover data were used). The significance of the matrix correlation coefficient was tested by Monte-Carlo simulation, and the number of permutations was 1000 . The distribution of life strategy types (During, 1992) of the two assemblages was compared by chi-square analysis of contingency tables (Zar, 1999).

Relationships between the bryophyte species composition of the diaspore bank and potential explanatory variables were explored by indirect (principal component analysis, PCA and detrended correspondence analysis, DCA) and direct (redundancy analysis, RDA) ordination (Legendre \& Legendre, 1998; Podani, 2000). Species data were centred and logarithmically transformed. Bryophyte species with lower frequency than four (occurred in less than five plots out of 35) were omitted from the analysis. As the gradient length of the DCA axes was lower than 1.5 
standard deviation unit, RDA was used for direct ordination. This method supposes an approximately linear relationship between the species abundance and the explanatory variables. The environmental factors of the redundancy analysis were selected by manual forward selection. The effect of factors was tested by F-statistics via Monte-Carlo simulation, the number of permutations was 499, and the threshold significance level was 0.05 (Ter Braak \& Smilauer, 2002; Lepš \& Šmilauer, 2003). The significance of all canonical axes was investigated similarly to the explanatory variables. Because of its significant effect, the longitudinal geographical coordinate was used as a covariate in the final ordination.

The relationship between the abundance of diaspore bank (dependent variable) and the environmental (explanatory) variables was tested by linear modelling, using Gaussian error structure without transformation (Faraway, 2005). As the longitudinal geographical coordinate had a significant effect, it was used as a covariable within a partial multiple regression framework (Legendre \& Legendre, 1998). Before modelling, preliminary selection and data exploration were performed. Only those explanatory variables were included in the linear model selection that (1) correlated significantly with the dependent variables; (2) had homogenous scatter plots with them; and (3) their inter-correlations with the other explanatory variables were low (the absolute values of the correlation coefficients were lower than 0.40 ). The minimal adequate model was built by backward elimination, using deviance analysis with F-test (ANOVA). The model selection was also checked by likelihood methods using the Akaike Information Criterion (Faraway, 2005). The normality and variance homogeneity of the residuals of the final model were checked. Multivariate analyses were carried out with Canoco for Windows 4.5 (Ter Braak \& Smilauer, 2002), whereas the rest of the analyses were carried out in the $\mathrm{R} 2.14 .0$ statistical environment (The $\mathrm{R}$ Development Core Team, 2011), using the vegan package for the Mantel-test (Oksanen et al., 2011).

\section{Results \\ Comparison of diaspore bank and forest-floor assemblages}

The diversity of the diaspore bank was lower than that of the forest-floor bryophyte assemblage. Only 13 bryophyte species occurred in the diaspore bank, while the whole sample of the forest-floor assemblage contained 70 species (Supplementary Material 1, Table S1). The mean species richness of plots was 5.80 (median 6) for the diaspore bank and 19.20 (median 18) for the forest-floor assemblage; the median of the two variables significantly differed

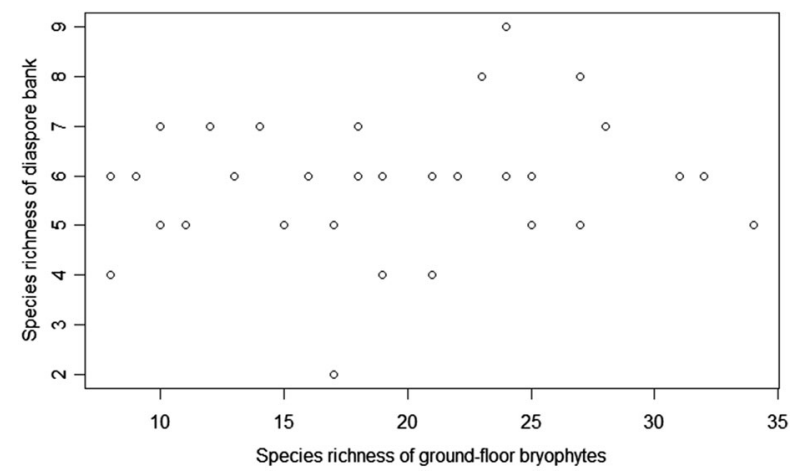

Figure 1 Relationships between forest-floor and diaspore bank assemblages according to species richness (species number per plot)

(Mood median test, $P<0.001$ ). Neither the species richness (Figure 1, $r=0.17, P=0.17$ ) nor the abundance ( $r=0.07, P=0.67$ ) of forest-floor and diaspore bank assemblages correlated. The composition of the life strategy types based on species abundance was different between the two assemblages (Figure 2, test of contingency tables, $\mathrm{Chi}^{2}=77375, \mathrm{df}=3, \quad P<$ $0.001)$. The diaspore bank was dominated by colonists, the forest-floor assemblage by perennials. The only exception was the perennial Atrichum undulatum, which was found frequently in both assemblages.

The species composition of the assemblages was significantly different, and the distance matrices of the plots derived from the two assemblages were significantly not correlated (Mantel-test, $r=0.151 ; P=0.095$ ). Many species occurred in the forest-floor vegetation but were absent from the diaspore bank, resulting in the lower species richness of the second assemblage (Supplementary Material 1, Table S1). The overlap in the species composition was low. Only Atrichum undulatum, Dicranella heteromalla and Pohlia nutans were abundant in both assemblages. However, many species (Dicranella rufescens, Philonotis arnellii, Physcomitrium pyriforme, Sphagnum spp. and Trichostomum

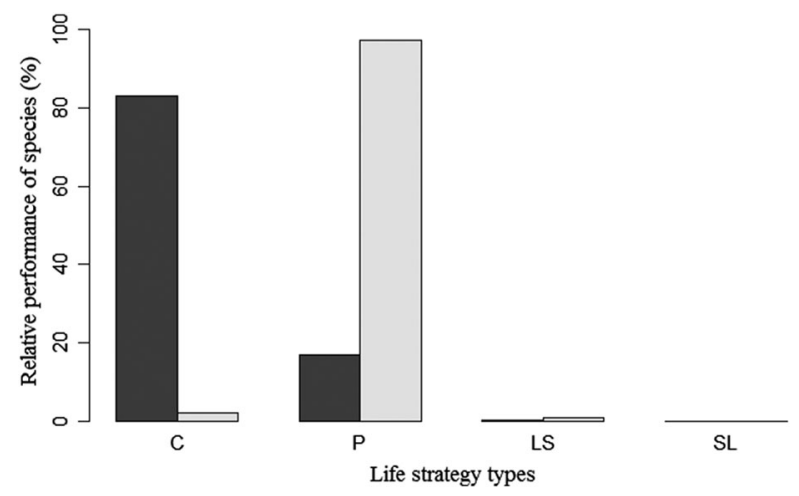

Figure 2 Distribution of the life strategy types in diaspore bank (black) and forest-floor (gray) assemblages based on the relative abundance of species. Strategy types: C colonist; P - perennial; LS - long lived shuttle; SL - short lived shuttle. 
brachydontium) occurred only in the diaspore bank, while Bryum rubens and Ditrichum spp. were dominant in the diaspore bank but rare in the forest-floor assemblage. Many abundant terricolous-opportunistic species (e.g. Brachythecium rutabulum, Dicranum scoparium, Hypnum cupressiforme, Polytrichum formosum) and epiphytic-epixylic (Dicranum montanum, Frullania dilatata, Lophocolea heterophylla, Platygyrium repens, Plagiothecium spp., Radula complanata) species of the forest-floor vegetation were absent from the diaspore bank. Some abundant species of the forest-floor assemblage occurred with very low local frequency in the diaspore bank (e.g. Brachythecium velutinum, Herzogiella seligeri and Rhizomnium punctatum). There was no germination in the three autoclaved control boxes included for detecting air-borne propagule contamination.

\section{Multivariate analysis of the diaspore bank}

The first and second PCA axes explained $43 \%$ and $22 \%$ of species variance, respectively. In contrast to species, the appearance of the plots along the PCA axes was not grouped (Figure 3). Atrichum undulatum, Dicranella heteromalla and Pohlia nutans had negative values along the first PCA axis, while Bryum rubens, Dicranum rufescens and Ditrichum spp. were separated based on the second PCA axis (they had negative values on it).

The canonical axes of RDA explained $45.8 \%$ of total variance (first axis $23.4 \%$, second $14.6 \%$, Figure 4). The effects of the first axis $(F=8.27, P=$ $0.002)$ and all canonical axes $(F=3.81, P=0.002)$

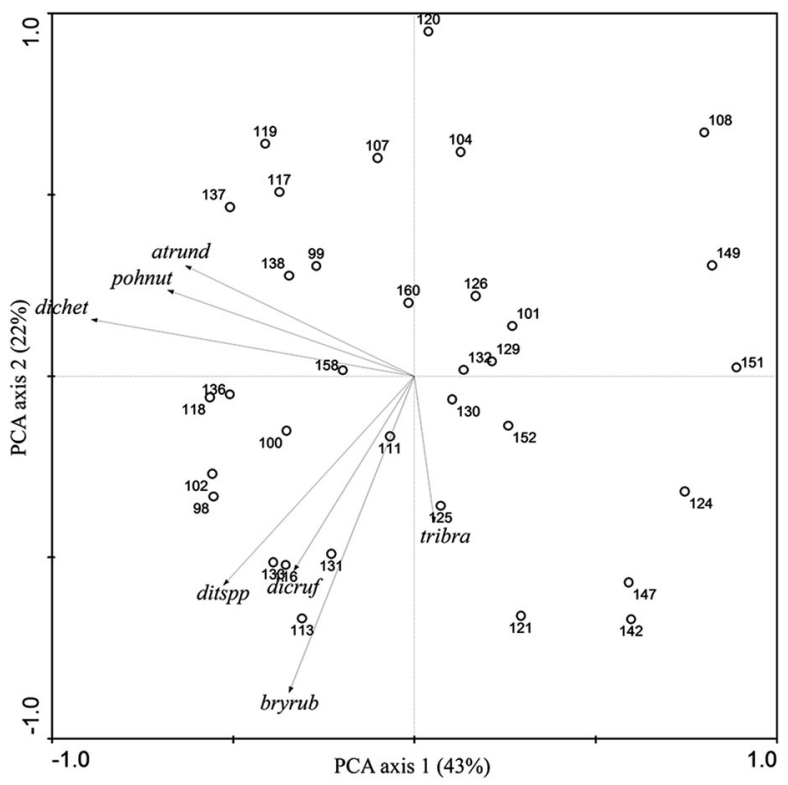

Figure 3 Biplot of the principal component analysis (PCA) of the diaspore bank. The first axis explained $43 \%$, the second $22 \%$ of the species variance. Species are marked by arrows and abbreviations, and the plots by open circles and numbers. Species abbreviation consists of the first three letters of the genus and species names (Supplementary Material 1, Table S1).

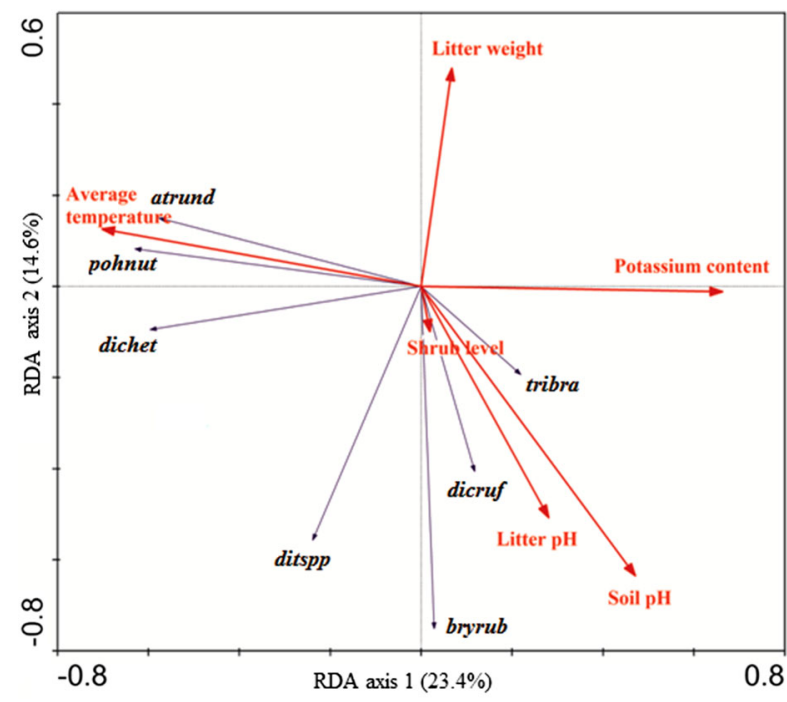

Figure 4 Species and environmental variables biplot of the redundancy analysis (RDA). The first axis explained $23 \%$, the second $15 \%$ of the species variance. Species abbreviation consists of the first three letters of the genus and species names (Supplementary Material 1, Table S1). Explanatory variables are represented with red arrows and letters, for description see Table 1.

Table 2 Names (variables), explained variance (variance\%), $F$ values $(F)$ and significance $(P)$ of the selected explanatory variables of the redundancy analysis

\begin{tabular}{lccc}
\hline Variables & Variance (\%) & $\boldsymbol{F}$ & $\boldsymbol{P}$ \\
\hline Average temperature & 13 & 4.68 & 0.004 \\
Soil pH & 9 & 3.57 & 0.016 \\
Soil potassium content & 7 & 2.96 & 0.032 \\
Litter weight & 6 & 2.70 & 0.026 \\
Litter pH & 6 & 2.87 & 0.024 \\
Shrub density & 5 & 2.46 & 0.038 \\
\hline
\end{tabular}

were significant. Average temperature, soil $\mathrm{pH}$, soil potassium content, litter weight, litter $\mathrm{pH}$ and shrub density were significant explanatory variables in the final RDA model (Table 2). The first axis correlated positively with soil potassium content and negatively with average temperature. The second axis had positive correlation with litter weight and negative with shrub density, litter $\mathrm{pH}$ and soil $\mathrm{pH}$. Three dominant acrocarpous species, Atrichum undulatum, Dicranella heteromalla and Pohlia nutans had positive correlation with average temperature and negative correlation with soil potassium content. Presence of Bryum rubens, Dicranum rufescens and Ditrichum spp. were affected mainly positively by shrub density, litter $\mathrm{pH}$ and soil $\mathrm{pH}$, and they were negatively related to litter weight.

Based on the multiple regression model $\left(R^{2}=0.23\right.$, $F_{3,31}=4.35, P=0.011$ ), the abundance of the diaspore bank was positively related to the cover of the understory and air temperature, while it was negatively related to soil acidity (Table 3 ). 
Table 3 Importance of the explanatory variables in the regression model of the diaspore bank abundance

\begin{tabular}{lrccc}
\hline Variables & Estimate & Variance (\%) & $\boldsymbol{F}$ & $\boldsymbol{P}$ \\
\hline Understory cover & 46.78 & 11.61 & 5.11 & 0.031 \\
Acidity & -40.25 & 8.29 & 3.65 & 0.065 \\
Temperature & 42.05 & 9.73 & 4.29 & 0.047 \\
\hline
\end{tabular}

\section{Discussion \\ Comparison of diaspore bank and forest- assemblages}

In this study, the direct comparison of forest-floor and diaspore bank species richness is difficult, because of the different sampling methodology: ground floor species richness was surveyed in the whole $900 \mathrm{~m}^{2}$ area, while the diaspore bank was analysed from 3 ca $50 \mathrm{~cm}^{3}$ soil cubes. The sampling intensity for diaspore bank was too low to estimate species richness for the whole $\left(900 \mathrm{~m}^{2}\right)$ area. It is also possible that not all potentially viable propagules germinated during our experiment. However, the compositional differences between diaspore bank subunits (expressed as Euclidean distance) were significantly lower for within plot than for between plot subunits (Supplementary Material 2). We interpret that the beta diversity of subunits within a plot is relatively low. Although the species richness of the diaspore bank was probably underestimated because of methodological limitations, the species richness difference between the diaspore bank and forest-floor vegetation was so high (13 versus 70 for the whole sample, 5.8 versus 19.2 for plot level) that it suggests important differences in total species richness between the diaspore bank and the forest-floor vegetation.

Contrary to our results, it has been shown that the diaspore bank can have similar or higher diversity than the actual forest-floor, both in temperate forests and grasslands (Jonsson, 1993; Hock, 2007; Hock et al., 2008; Vanderpoorten \& Goffinet, 2009). In tropical rain forests, a similarly species poor diaspore bank was observed, because of the inhibitory effect of the litter layer (Maciel-Silva et al., 2012). The low diversity of the diaspore bank could be explained by the regular, long-term disturbance of the forest soil. Many stands were ploughed in the past, and the soil surface of the regenerated forests has been regularly disturbed by forestry activities. Chronic disturbance could deplete the diaspore bank (Jonsson, 1993; During, 1997), especially if its species are very rare in the forest-floor vegetation.

In our case, the low diversity of diaspore bank can partly be explained by the large compositional difference between the diaspore bank and the forest-floor assemblages. These two assemblages were different; only two species (Atrichum undulatum and Dicranella heteromalla) had considerable abundance in both groups. Liverworts did not establish a diaspore bank in the studied temperate forests, which is confirmed by earlier results from boreal (Jonsson, 1993; RossDavis \& Frego, 2004) and tropical regions (MacielSilva et al., 2012; but see Bisang et al., 2003; Caners et al., 2009). Some dominant species of the forestfloor vegetation that produce huge numbers of spores (e.g. Hypnum cupressiforme and Polytrichum formosum) were not present in the diaspore bank. The absence of Polytrichum formosum is a surprising result, because it was fairly abundantly present in several previous studies (During et al., 1987; Jonsson, 1993; Iglesias et al., 2015).

Short-lived colonist mosses were dominant in the diaspore bank, as opposed to the forest floor bryophyte community, where perennial mosses dominated. These results are confirmed by many previous studies (e.g. During, 1979, 1997; During \& ter Horst, 1983; During \& van Tooren, 1987). Szücs (2013) noticed similar species in the diaspore bank of Hungarian beech forests, namely, Pohlia nutans was the most abundant species, and Atrichum undulatum, Bryum spp. and Dicranella heteromalla were also frequent.

\section{Multivariate analysis of the diaspore bank}

Atrichum undulatum, Dicranella heteromalla and Pohlia nutans preferred relatively warm, more open, nutrient poor stands, while Bryum rubens, Dicranum rufescens and Ditrichum spp. were associated with stands with relatively less acidic litter and soil conditions. Other studies focusing on the propagule bank also confirm that Pohlia nutans prefers relatively acidic soil conditions both in boreal (Rydgren et al., 2004; Caners et al., 2009) and mixed forests (RossDavis \& Frego, 2004).

Litter accumulation could prevent the establishment of bryophytes in the study area, both in the diaspore bank and on forest floor (Márialigeti et al., 2009). A similar phenomenon was observed in other regions, both in wetlands (Peintinger \& Bergamini, 2006) and forests (Dzwonko \& Gawronski, 2002; Légaré et al., 2005; Startsev et al., 2008). Based on our results, both species composition and the abundance of the diaspore bank were positively influenced by higher air temperature. Relatively higher temperatures could accelerate the germination of the propagule bank after disturbance (During, 1979, 1997; Schofield, 1985; Risse, 1987; Wiklund \& Rydin, 2004; Caners et al., 2009). Soil temperature and humidity can have a more direct effect on the propagule bank than the measured air temperature and humidity, but these variables are strongly related. Our findings that the potassium content had a negative effect, while soil and litter $\mathrm{pH}$ had a positive influence on the germination of the diaspore bank propagules have been supported by a number of studies (During, 1979, 1997; 
Schofield, 1985; Risse, 1987; Wiklund \& Rydin, 2004; Caners et al., 2009; Rydin, 2009; Maciel-Silva et al., 2012).

Light is a very important environmental variable for the forest bryophyte vegetation (Wiklund \& Rydin, 2004; Kimmerer, 2005; Caners et al., 2009), but our results show that it was not a significant environmental variable for the diaspore bank. Light influences spore germination and gametophyte growth that could eventually influence competitive relations (During, 1979; Schofield, 1985; Vanderpoorten \& Goffinet, 2009). The understory layer and shrub density had a positive effect on the propagule bank, similarly to our results for forest-floor bryophytes (Márialigeti et al., 2009). These factors could produce a favourable microclimate not only for the terrestrial bryophytes, but also for the diaspore bank after disturbance. Since light is not an influential environmental variable in our study, this positive effect of the microclimate may overwhelm the negative shading effect of the understory and shrub layers. Contrary to our results, herbaceous and bryophyte cover negatively influenced the germination of the diaspore bank in many cases (Virtanen et al., 2000; Peintinger \& Bergamini, 2006). Similarly to Caners et al. (2009), landscape variables and management history were not directly influential on the propagule bank. The frequent disturbances in the past could have had an important effect on the deterioration of the propagule bank, but the effect of land use history is not traceable in the recent assemblages. The longitudinal geographical extent of the study had significant effect, but it is very difficult to relate it to direct environmental variables. Because its direct effect was not a target of this study we used it as a covariable during the analyses.

Summarizing, as opposed to the forest-floor bryophyte assemblages (Márialigeti et al., 2009), where substrate availability, tree species composition and stand forest structure were the most influential environmental variables, the diaspore bank was affected mainly by forest site conditions (microclimate, litter and soil properties). It is in accordance with the study of Caners et al. (2009) from boreal forests, in that light conditions, $\mathrm{pH}$ and potassium content were the most important factors affecting the diaspore bank.

\section{Conclusions}

Large differences were observed between the propagule bank and the forest-floor assemblages in respect of species richness, species composition and limiting environmental factors. Bryophyte species can regenerate from diaspore bank, by propagule dispersal or clonal expansion (Jonsson, 1993; Rydgren \& Hestmark, 1997). In this study, we conclude that the role of the bryophyte diaspore bank is relatively low in the regeneration and maintenance of the forest-floor bryophyte vegetation in the mixed forests of Central Europe. In the establishment, maintenance and regeneration of the forest-floor bryophyte vegetation, the most important processes are clonal expansion (regeneration) and colonization by airborne propagules. The diaspore bank can be an essential part of the life history for some short-lived species, but it is not important to the establishment of the dominant forest-floor species because they have different life histories, without the production of longlived soil dwelling diaspores (During, 1979, 1997).

\section{Acknowledgements}

The authors thank Zsófia Hock for methodological advice, participants of the Örs-Erdö project for environmental data collection, and the Department of Plant Taxonomy, Ecology and Theoretical Biology for providing the infrastructure. This study was supported by the Hungarian Research Fund (OTKA 79158), the Directory of Örség National Park and the TÁMOP-4.2.2.D-15/1/KONV-20150023 project of the European Union and European Social Found. Péter Ódor is a grantee of the János Bolyai Scholarship of the Hungarian Academy of Sciences.

\section{Supplemental data}

Supplemental data for this article can be accessed 10.1080/03736687.2015.1115804.

Taxonomic Additions and Changes: Nil.

\section{References}

Arcanum. 2006. Digitized maps of the Habsburg Empire. The Second Military Survey 1806-1869. DVD-Rom. Budapest: Arcanum Kft.

Aude, E. \& Lawesson, J.E. 1998. Vegetation in Danish beech forests: the importance of soil, microclimate and management factors, evaluated by variation partitioning. Plant Ecology, 134: 53-65.

Bisang, I., Piippo, S. \& Hedenäs, L. 2003. Bryophyte diaspore bank in three Malaysian mountain rainforests. Journal of Bryology, 25: $68-70$.

Caners, R.T., Macdonald, S.E. \& Belland, R.J. 2009. Recolonization potential of bryophyte diaspore banks in harvested boreal mixed-wood forest. Plant Ecology, 204: 55-68.

Csontos, P. 2001. A természetes magbank kutatásának módszerei [Methods for studying the natural seed bank]. Budapest: Scientia Kiadó, Synbiologia Hungarica 4.

During, H.J. 1979. Life strategies of bryophytes: a preliminary review. Lindbergia, 5: 2-18.

During, H.J. 1992. Ecological classifications of bryophytes and lichens. In: J.W. Bates and A.M. Farmer, eds. Bryophytes and lichens in a changing environment. Oxford: Clarendon Press, pp. 1-31

During, H.J. 1995. Population regulation in tuber-bearing mosses: a simulation model. Lindbergia, 20: 26-34.

During, H.J. 1997. Bryophyte diaspore banks. Advances in Bryology, 6: $103-34$.

During, H.J. 2001. Diaspore banks. Bryologist, 104: 92-7.

During, H.J. \& ter Horst, B. 1983. The diaspore bank of bryophytes and ferns in chalk grassland. Lindbergia, 9: 57-64.

During, H.J. \& van Tooren, B.F. 1987. Recent developments in bryophyte population ecology. Trends in Ecology \& Evolution, 2: 89-93. 
During, H.J., Brugués, M., Cros, R.M. \& Lloret, F. 1987. The diaspore bank of bryophytes and ferns in the soil in some contrasting habitats around Barcelona, Spain. Lindbergia, 13: 137-49.

Dzwonko, Z. \& Gawronski, S. 2002. Effect of litter removal on species richness and acidification of a mixed oak-pine woodland. Biological Conservation, 106(3): 389-98.

Erzberger, P. \& Papp, B. 2004. Annotated checklist of Hungarian bryophytes. Studia Botanica Hungarica, 35: 91-149.

Faraway, J.J. 2005. Linear models with $R$. London: Chapman and Hall.

Gyöngyössy, P. 2008. "Gyántásország” Történeti adatok az örségi erdők erdészeti és természetvédelmi értékeléséhez [Historical records for the evaluation of the forests in Örség region] Szombathely: Kerekerdő Alapítvány.

Hebrard, J.P. 2001. Diaspore bank of bryophytes in the holm oak ecosystem of the Bois d'Astros in Vidauban (Var, France). Nova Hedwigia, 73: 323-37.

Hock, Zs. 2007. Propagule banks in bryophytes and ferns: dynamics, genetic composition and the role of the life history. $\mathrm{PhD}$ thesis, University of Zürich.

Hock, Zs., Szövényi, P. \& Tóth, Z. 2004. Seasonal variation in the bryophyte diaspore bank of open grasslands on dolomite rock. Journal of Bryology, 26: 285-92.

Hock, Zs., Szövényi, P., Schneller, J.J., Tóth, Z. \& Urmi, E. 2008. Bryophyte diaspore bank: a genetic memory? Genetic structure and genetic diversity of surface populations and diaspore bank in the liverwort Mannia fragrans (Aytoniaceae). American Journal of Botany, 95: 542-8.

Hylander, K. \& Dynesius, M. 2006. Causes of the large variation in bryophyte species richness and composition among boreal streamside forests. Journal of Vegetation Science, 17: 333-46.

Iglesias, N., Delgado, V. \& Ederra, A. 2015. A comparison between the diaspore bank and above-ground bryoflora in the beech forests of Navarra (Northern Spain). Cryptogamie, Bryologie, 36: $19-40$.

Jonsson, B.G. 1993. The bryophyte diaspore bank and its role after small-scale disturbance in a boreal forest. Journal of Vegetation Science, 4: 819-26.

Juhász, P., Bidló, A., Ódor, P., Heil, B. \& Kovács, G. 2011. Örségi erdőtalajok széntartalmi vizsgálata [Soil carbon content of soils in forest of Orség region]. Talajvédelem, Supplement: 377-82.

Kimmerer, R.W. 2005. Patterns of dispersal and establishment of bryophytes colonizing natural and experimental treefall mounds in northern hardwood forests. Bryologist, 108: 391-401.

Király, I. \& Ódor, P. 2010. The effect of stand structure and tree species composition on epiphytic bryophytes in mixed deciduous-coniferous forests of Western Hungary. Biological Conservation, 143: 2063-9.

Király, I., Nascimbene, J., Tinya, F. \& Ódor, P. 2013. Factors influencing epiphytic bryophyte and lichen species richness at different spatial scales in managed temperate forests. Biodiversity and Conservation, 22: 209-23.

Laaka-Lindberg, S. 1999. A sexual reproduction in a population of a leafy hepatic species Lophozia silvicola Buch in central Norway. Plant Ecology, 141: 137-44.

Légaré, S., Paré, D., \& Bergeron, Y. 2005. Influence of aspen on forest floor properties in black spruce-dominated stands. Plant and Soil, 275: 207-20.

Legendre, P. \& Legendre, L., 1998. Numerical ecology. Amsterdam: Elsevier.

Lepš, J. \& Šmilauer, P. 2003. Multivariate analysis of ecological data using Canoco. Cambridge: Cambridge University Press.

Lloret, F. 1994. Gap colonization by mosses on a forest floor: an experimental approach. Lindbergia, 19: 122-28.

Longton, R.E. 1997. Reproductive biology and life-history strategies. Advances in Bryology, 6: 65-101.

Maciel-Silva, A.S., Válio, I.F.M. \& Rydin, H. 2012. Diaspore bank of bryophytes in tropical rain forests: the importance of breeding system, phylum and microhabitat. Oecologia, 168: 321-33.

Márialigeti, S., Németh, B., Tinya, F. \& Ódor, P. 2009. The effects of stand structure on ground-floor bryophyte assemblages in temperate mixed forests. Biodiversity and Conservation, 18: 2223-41

Mills, S.E. \& Macdonald, S.E. 2005. Factors influencing bryophyte assemblage at different scales in the Western Canadian boreal forest. Bryologist, 108: 86-100.

Ódor, P. \& van Hees, A.F.M. 2004. Preferences of dead wood inhabiting bryophytes for decay stage, log size and habitat types in Hungarian beech forests. Journal of Bryology, 26: 79-95.
Ódor, P. \& Standovár, T. 2002. Substrate specificity and community structure of bryophyte vegetation in a near-natural montane beech forest. Community Ecology, 3: 39-49.

Ódor, P., Szurdoki, E. \& Tóth, Z. 2002. Az Örségi és a Vendvidék főbb élőhelyeinek mohavegetációja és flórája. [The bryophyte vegetation of important habitats in the Orség Protected Landscape Area (Hungary)]. Kanitzia, 10: 15-60.

Oksanen, J., Blanchet, F.G., Kindt, R., Legendre, P., Minchin, P.R., O'Hara, R.B., Simpson, G.L., Solymos, P., Henry, M., Stevens, H. \& Wagner, H. 2011. Vegan: Community Ecology Package. $\mathrm{R}$ package version 2.0-1 [accessed date 25 September 2015]. Available at: <http://CRAN.R-project.org $/$ package $=$ vegan $>$

Peintinger, M. \& Bergamini, A. 2006. Community structure and diversity of bryophytes and vascular plants in abandoned fen meadows. Plant Ecology, 185: 1-17.

Podani, J. 2000. Introduction to the exploration of multivariate biological data. Leiden: Backhuys Publishers.

Risse, S. 1987. Rhizoid gemmae in mosses. Lindbergia, 13: 111-26.

Ross-Davis, A.L. \& Frego, K.A. 2004. Propagule sources of forest floor bryophytes: spatiotemporal compositional patterns. Bryologist, 107: 88-97.

Rydgren, K. \& Hestmark, G. 1997. The soil propagule bank in a boreal old-growth spruce forest: changes with depth and relationship to aboveground vegetation. Canadian Journal of Botany, 75: 121-28.

Rydgren, K., Økland, R.H. \& Hestmark, G. 2004. Disturbance severity and community resilience in a boreal forest. Ecology, 85(7): 1906-15.

Rydin, H. 2009. Population and community ecology of bryophytes. In: B. Goffinet \& A.J. Shaw, eds. Bryophyte biology. Cambridge: Cambridge University Press, pp. 393-444.

Schofield, W.B. 1985. Introduction to bryology. New York: Macmillan Publishing Company.

Söderström, L. \& Herben, T. 1997. Dynamics of bryophyte metapopulations. Advances in Bryology, 6: 205-40.

Startsev, N., Lieffers, V.J. \& Landhausser, S.M. 2008. Effects of leaf litter on the growth of boreal feather mosses: implication for forest floor development. Journal of Vegetation Science, 19: 253-60.

Sundberg, S. \& Rydin, H. 2000. Experimental evidence for a persistent spore bank in Sphagnum. New Phytologist, 148(1): 105-16.

Szodfridt, I. 1969. Adatok az Örség erdőinek termőhelyi adottságaihoz [Forest site data for the forests of Örség region]. Vasi Szemle, 23: 386-94.

Szücs, P. 2013. A mohák megjelenését meghatározó egyes ökológiai tényezök vizsgálata a Soproni-hegységben [Environmental factors influencing bryophyte occurrences in Sopron Hills, Hungary]. PhD thesis, University of West, Hungary.

Ter Braak, C.J.F. \& Šmilauer, P. 2002. CANOCO 4.5: Biometrics. Wageningen: Wageningen University and Research Center.

The $\mathbf{R}$ Development Core Team. 2011. R. 2.14.0. A language and environment. Available at: <www.r-project.org $>$.

Tímár, G., Ódor, P. \& Bodonczi, L. 2002. Az Örségi és a Vendvidék erdeinek jellemzése. [Description of forests in Örség and Vendvidék region]. Kanitzia, 10: 109-36.

Tinya, F., Márialigeti, S., Király, I., Németh, B. \& Ódor, P. 2009. The effect of light conditions on herbs, bryophytes and seedlings of temperate mixed forests in Orség, Western Hungary. Plant Ecology, 204(1): 69-81.

Tutin, T.G., Heywood, V.H., Burges, N.A., Valentine, D.H., Walters, S.M. \& Webb, D.A. 1964-1993. Flora Europaea. Cambridge: Cambridge University Press.

Vanderpoorten, A. \& Goffinet, B. 2009. Ecology. In: A Vanderpoorten \& B. Goffinet, eds. Introduction to bryophytes. Cambridge: Cambridge University Press, pp. 153-84.

Van Tooren, B.F., Odé, B., During, H.J. \& Bobbink, R. 1990. Regeneration of species richness in the bryophyte layer of Dutch chalk grasslands. Lindbergia, 16: 153-60.

Virtanen, R., Johnston, A.E., Crawley, M.J. \& Edwards, G.R. 2000. Bryophyte biomass and species richness on the Park Grass Experiment, Rothamsted, UK. Plant Ecology, 151: 129-41.

Wiklund, K. \& Rydin, H. 2004. Ecophysiological constraints on spore establishment in bryophytes. Functional Ecology, 18: $907-13$.

Zander, R.H. \& During, H.J. 1999. Neophoenix (Pottiaceae), a new African moss genus found through soil diaspore bank analysis. Taxon, 48: 657-62

Zar, J.H. 1999. Biostatistical analysis. New Jersey: Prentice Hall. 